\title{
RANCANG BANGUN ALAT UJI TARIK SERAT ALAM UNTUK MENDUKUNG INDUSTRI NASIONAL
}

\author{
Abubakar Dabet ${ }^{1)}$, Ferry Safriwardi ${ }^{2)}$ dan Ali Jannifar ${ }^{3)}$ \\ ${ }^{1,2)}$ Jurusan Teknik Mesin, Universitas Malikussaleh, Aceh Utara \\ ${ }^{3)}$ Jurusan Teknik Mesin, Politeknik Negeri Lhokseumawe, Lhokseumawe \\ e-mail: ${ }^{1}$ abubakar@unimal.ac.id
}

\begin{abstract}
Currently the development trend of composite materials shifts to the reuse of natural fiber (back to nature) as a substitute for synthetic fibers. Measurement of the mechanical properties of fiber (reinforcement) plays an important role in quality control. One of the most important mechanical properties of fiber is its tensile strength. Tensile strength of fiber can be known through tensile test (tensile test). To do tensile test (tensile test) fiber required tensile test machine (tensile test machine). The tensile test equipment used today is a foreign-made commercial tensile test device imported at an exorbitant price. These conditions cause obstacles in the development of basic industries and natural fiber technology. Most laboratories in higher education institutions and other technology research institutions do not have tensile test equipment support. The purpose of this research is to design a natural fiber tensile test apparats which is cheap and easy to operate. The research method using design tool design (design and manufacture). The result of this research is prototype of natural fiber tensile test which has been successfully tested with technical data: $5 \mathrm{~N}$ loading capacity, calibration curve accuracy: $N=1.052 \mathrm{~V}$ and loading rate $0.014 \mathrm{~N} / \mathrm{s}$. The result of tensile test to one natural fiber that used abaca fiber obtained the value of tensile strength of an average of 579,90 MPa. The result of tensile test obtained is comparable with the data of tensile test results in existing literatures then there is conformity with the value of tensile strenght. The results of this study are expected to provide benefits for researchers, academics and industry in supporting the development of national natural fiber industry to increase the competitiveness of industries at the international level.
\end{abstract}

Keywords: Tensile testing apparatus, tensile strenght, natural fiber, abaca fiber, design.

\section{PENDAHULUAN}

Pada dasawarsa terakhir, kecenderungan perkembangan material komposit bergeser pada penggunaan serat alam kembali (back to nature) sebagai pengganti serat sintetik. Hal ini didukung oleh beberapa keunggulan yang dimiliki oleh serat alam, diantaranya adalah massa jenisnya rendah, terbaharukan, produksi memerlukan energi yang rendah, proses lebih ramah, serta mempunyai sifat insulasi panas dan akustik yang baik [1].

Penggunaan serat alam juga dipicu oleh adanya regulasi tentang persyaratan habis pakai (end of life) produk komponen otomotif bagi negara-negara Uni Eropa dan sebagian Asia. Sejak tahun 2006, negara-negara Uni Eropa telah mendaur ulang 80\% komponen otomotif, dan akan meningkat menjadi 85\% pada tahun 2015. Di Asia khususnya Jepang, pada tahun 2005 sekitar 88\% komponen otomotif telah didaur ulang, sedangkan pada tahun 2015 ditargetkan komponen yang dapat didaur ulang meningkat menjadi sekitar 95\% [2]. Untuk itu, sebagian besar pabrikan otomotif sedang mengevaluasi dampak lingkungan terhadap umur pakai kendaraan secara keseluruhan mulai dari bahan baku, proses manufaktur sampai pada proses pembuangannya ketika sudah tua.

Serat berfungsi sebagai penguat (reinforcement) pada material komposit. Proses manufaktur material komposit, pengukuran sifat mekanik serat (reinforcement) berperan penting dalam kontrol kualitas. Kekuatan tarik serat adalah besarnya gaya yang dibutuhkan untuk menarik serat tunggal sampai titik putus dan merupakan salah satu sifat mekanik yang sangat penting untuk analisis dan perancangan bahan berstruktur komposit [3]. Metode mengukur modulus dan kekuatan serat dengan melakukan uji tarik pada untaian serat tunggal sangat populer di industri manufaktur serat [4].

Dari hasil uji tarik kita dapat melakukan pemilihan material untuk aplikasi tertentu, kita dapat memprediksi bagaimana respon material terhadap berbagai jenis sistem pembebanan gaya. Prosedur eksperimental untuk mengukur Modulus Young's dan tegangan tarik dari serat tunggal sudah diterangkan dalam detail pengujian ini [5]. Syarat-syaratnya sudah ditentukan menurut 
Standar ASTM D3379-75 [6]. Metode-metode uji tarik lainnya dapat dilihat pada hasil penelitian [7-9].

Komposit serat alam mempunyai prospek yang sangat baik untuk dikembangkan di Indonesia. Beberapa alasan diantaranya adalah bahwa mayoritas tanaman penghasil serat alam dapat dibudidayakan di Indonesia, misalnya adalah serat abaca, kenaf, rami, rosella dan nanasnanasan [10]. Pengembangan teknologi komposit berpenguat serat alam sejalan dengan kebijakan pemerintah untuk menggali potensi local genius yang ada. Hal ini akan mampu meningkatkan pemberdayaan sumber daya alam lokal yang dapat diperbaharui. Bahkan, keberhasilan pengembangan komposit serat alam ini akan mampu meningkatkan nilai teknologi dan nilai ekonomi serat alam. Sampai saat ini komposit serat alam belum banyak digunakan di berbagai industri di Indonesia. Berbagai kendala yang ada termasuk masih minimnya penguasaan teknologi pengelolaan serat alam mulai dari pembudidayaan sampai pada tahapan pasca panen.

Secara khusus untuk mengetahui kekuatan tarik serat alam diperlukan alat uji tarik. Alat uji tarik yang digunakan saat ini merupakan alat uji tarik komersil buatan luar negeri yang di import dengan harga yang mahal sekali. Kondisi tersebut menyebabkan kendala dalam pengembangan industri dasar dan teknologi serat alam. Kebanyakan laboratorium di lembaga pendidikan tinggi dan lembaga riset teknologi lainnya tidak mempunyai peralatanuji tarik. Tujuan penelitian ini adalah melakan rancang bangun alat uji tarik serat alam yang murah harganya dan mudah dalam pengoperasian. Hasil penelitian ini diharapkan dapat memberikan manfaat bagi peneliti, akademisi dan industri dalam mendukung perkembangan industri serat alam nasional untuk peningkatan daya saing industri pada level internasional.

\section{METODE PERANCANGAN \\ Desain Konsep}

Perencanaan awal adalah tahapan paling dasar mengenai proyek perancangan yang akan dilakukan, dalam hal ini adalah pembuatan rancangan rancangan awal dari produk alat uji tarik serat alam dengan acuan data-data yang telah dikumpulkan sebeumnya. Hasil rancangan awal ini nantinya akan digunakansebagai acuan pada tahapan perhitungan teknik. Desain konsep dari rancangan alat uji tarik serat alam adalah gambaran secara garis besar mengenai alat yang akan dibuat dan akan mempermudah dalam perhitungan teknik. Data primer desain konsep alat uji tarik serat alam adalah:

a. Kapasitas pembebanan (gaya) sebesar $5 \mathrm{~N}$.

b. Baja profil L, Hot Rolled JIS SS40/A36 (07.2054 ISO1990), ukuran: 40 mm x 40 mm, tebal 4 mm dan panjang $800 \mathrm{~mm}$.

c. Bajal profil U; Ukuran: lebar $65 \mathrm{~mm}$ x tinggi $42 \mathrm{~mm}$ x tebal 5,5 mm dan panjang $600 \mathrm{~mm}$.

d. Baja profil L, Hot Rolled JIS SS40/A36 (07.2054 ISO1990); Ukuran: lebar 30 mm x tebal 3 mm $\mathrm{x}$ panjang $150 \mathrm{~mm}$.

e. Baja ukuran $50 \mathrm{~mm}$ x $100 \mathrm{~mm}$ x $10 \mathrm{~mm}$ digunakan untuk penjepit batang cantilever.

f. Batang cantilever plat kuningan dengan modulus elastisitas sebesar $110 \mathrm{GPa}$, kekuatan tarik sebesar (570 sd. 665) MPa dan Rasio Poison sebesar 0,33.

\section{Model Pembebanan Gaya}

Suatu model perhitungan yang sederhana dapat menghasilkan kurva kalibrasi. Dengan memperhatikan sebuah batang cantilever, panjang $1 \mathrm{~mm}$, tebal $2 \mathrm{~mm}$ and lebar $4 \mathrm{~mm}$, serta Modulus Young (E), $110 \mathrm{GPa}$. Ketika batang cantilever ini mengalami pembebenan sebesar $P$ pada ujungnya maka besarnya momen yang terjadi M, dapat dihitung sebagai berikut [11]:

$\mathrm{M}=\mathrm{Px}$

Dengan, $\mathrm{x}$ adalah jarak dari titik pembebanan. Tegangan bending yang terjadi pada titik ini adalah: 
$\sigma=\frac{M}{Z}=\frac{P x}{\frac{b h^{2}}{6}}$

Dengan, $\mathrm{Z}$ adalah modulus bidang, $\mathrm{b}$ and h adalah lebar dan tebal dari batang cantilever. Jika bekerja pada kondisi elastis maka dapat dipterapak Hukum Hook, dan kemudian besarnya regangan yang terjadi adalah:

$\varepsilon=\frac{\sigma}{E}=\frac{6 P x}{b h^{2} E}$

Dengan E adalah Modulus Young

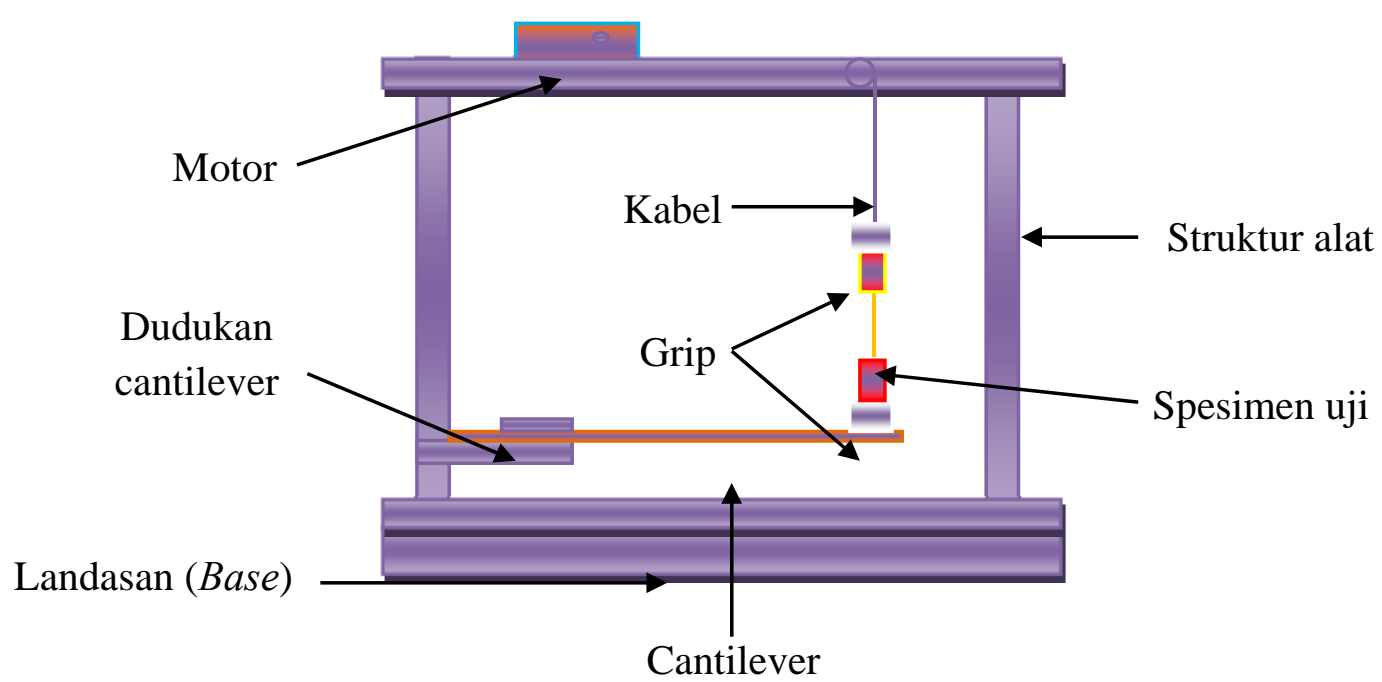

Gambar 1. Desain konstruksi alat uji tarik.

Selanjutnya dipertimbangkan output dari dua strain gauges, ketika akan mencoba mengukur regangan biasanya digunakan strain gauges, untuk mengukur regangan pada posisi strain gauges dipasang. Prinsip pengukuran regangan menggunakan strain gauges dapat dijelaskan sebagai berikut:

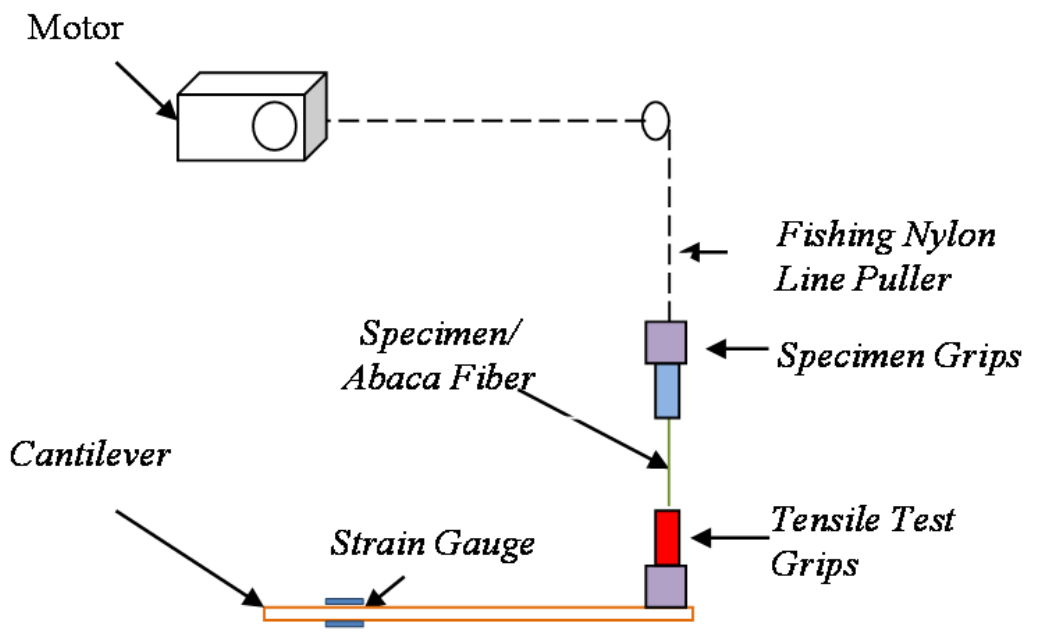

Gambar 2. Sistem pengukuran pembebanan 
Pada Gambar 2 di atas ditunjukkan sepasang strain gauges yang merupakan komponen yang sangat tipis yang sangat responsif terhadap tegangan (gaya). Jika panjang resistansinya adalah $L$ mm dan mengalami pertambahan panjang sebesar $\Delta L$, maka resistansinya akan berubah dari $R$ menjadi $R+\Delta R$. Perubahan resistansi ini dapat dihitung sebagai berikut:

$R=\rho \frac{L}{A}$

Dengan: A luas penampang resistansi. $\rho$ adalah resistansi specific listrik. Apabila kita mengambil differensiasi legalistik dari kedua sisinya maka,

$\frac{d R}{R}=\frac{d L}{L}-\frac{d A}{A}$

Dengan hukum Hooked dapat digunakan untuk menghitung $\frac{d A}{A}$.

Ditinjau sebuah batang round bar dengan diameter sebesar d, dan round bar mengalami regangan sebesar $\varepsilon$ dalam arah longitudinal. Diameter akan mengalami pengecilan karena pengaruh Poisson, pengurangan diameter ini dapat dihitung sebagai berikut:

$\frac{\Delta d}{d}=-v \varepsilon$

Karena itu, pengurangan luas penampang sebesar:

$$
\begin{aligned}
\Delta A & =\frac{\pi(d-\Delta d)^{2}}{4}-\frac{\pi d^{2}}{4} \\
& =\frac{\pi d^{2}}{4}\left[\left(1-\frac{\Delta d}{d}\right)^{2}-1\right]=-A \frac{2 \Delta d}{d}=-2 A \nu \varepsilon
\end{aligned}
$$

Dengan mensubstitusikan persamaan 3.6 dan 3.7 ke dalam pers. 3.5, maka kita dapatkan:

$\frac{d R}{R}=(1+2 v) \varepsilon=K_{S} \varepsilon$

Dengan $K_{s}$ adalah faktor gauges (nilainya sebesar 2 untuk kebanyakan gauges).

\section{Jembatan H (H-Bridge Circuit)}

Untuk mengukur laju perubahan resistansi dari strain gauges, kita dapat menggunakan sebuah jembatan rangkaian (bridge circuit) untuk mengubah besaran resistansi menjadi tegangan. Prinsip dari jembatan rangkaian (bridge circuit) dapat dijelaskan menggunakan model pembebabanan cantilever seperti yang dimaksudkan di atas.

Pada Gambar 3, sebuah jembatan rangkaian (bridge circuit) digunakan untuk penelitian ini. Pada sisi A-B, disambung wayar listrik yang berasal dari sisi bawah strain gauges yang terpasang pada cantilever, sedangkan pada sisi A-D, disambung wayar listrik yang berasal dari sisi atas strain gauges. Pada sisi B-C, dan C-D, besarnya resistansi terpasang $120 \Omega$.

Ketika batang cantilever diberikan momen bengkok sebesar $\mathrm{M}$, menyebabkan terjadi beban bengkok. Nilai resistansi dari kedua strain gauges berubah dengan nilai sama tetapi arah yang berbeda. Pada kasus ini, besarnya arus yang mengalir sepanjang sisi A-B-C berbeda dengan yang mengalir pada A-D-C, tetapi perbedaannya sangat kecil. Oleh sebab itu, untuk menyederhanakannya, besarnya arus ditentukan sebesar $i=V o / R$. Sehingga, beda potensial $\Delta V$ pada titik B and D dapat dihitung sebagai berikut: 


$$
\begin{array}{rlrl}
\Delta V= & (R+\Delta R) i-(R-\Delta R) i=2 \Delta R . V o / R=2 V o . \Delta R / R=2 V_{o} K s \mathcal{E} \\
= & 12 K_{S} V o^{x} & P \\
& b 2 E
\end{array}
$$

Dengan faktor sebelum P adalah kemiringan dari kurva kalibration.

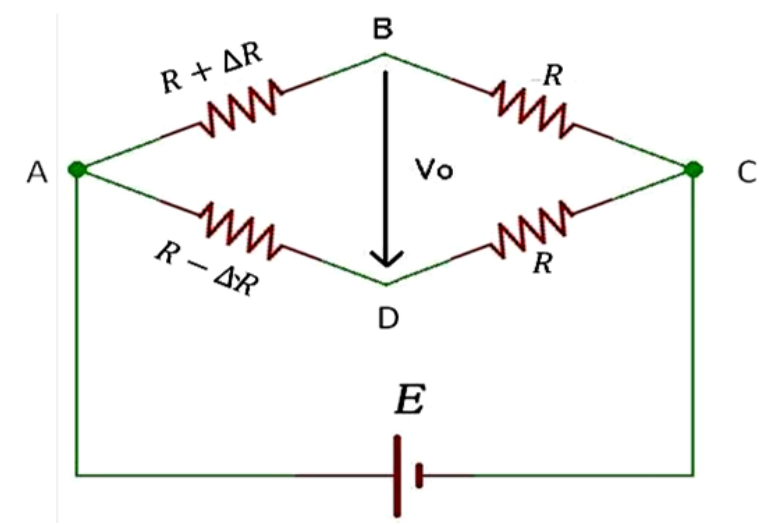

Gambar 3. Jembatan rangkaian (Bridge Circuit Two Gauges Method).

\section{METODE}

\section{Penyiapan Spesimen Uji Tarik}

Diameter spesimen uji tarik serat alam diukur menggunakan mikroskop optik, tidak digunakan micrometer atau jangka sorong karena serat alam agak lunak. Pengukuran diameter serat alam dilakukan pada tiga posisi spesimen yaitu: posisi tengah dan pada dua posisi ujung. Dari ketiga posisi pengukuran tersebut diambil harga rata-rata diameter serat [12]. Penampang serat alam tidak bulat sempurna sehingga pada setiap posisi pengukurannya dilakukan dua kali dengan memutar sebesar $90^{\circ}$ seperti terlihat pada Gambar 4 di bawah ini.

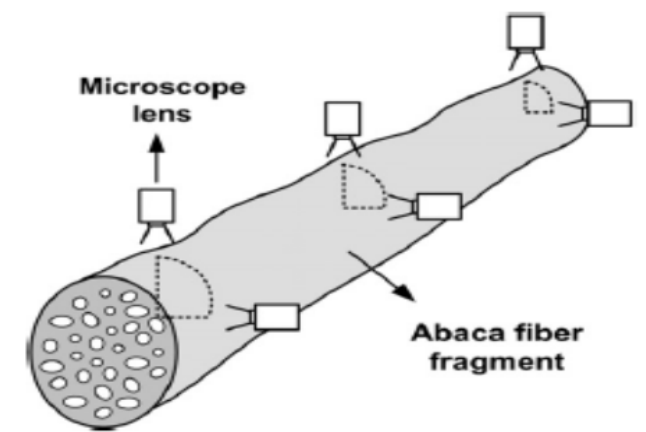

Gambar 4. Skema pengukuran diameter rata-rata serat.

\section{Geometri Spesimen Uji Tarik}

Spesimen uji serat alam dipersiapkan seperti di bawah ini. Penyangga serat dibuat dari kertas ukuran $20 \mathrm{~mm}$ x $100 \mathrm{~mm}$, dimana ukuran spesimen uji tarik tersebut mengikuti standar JIS K-760 seperti pada Gambar 5.

\section{Sistem Akuisisi Data}

Sistem akuisisi data yang digunakan dalam penelitian ini seperti yang ditunjukkan pada Gambar 6. Sinyal luaran yang berasal dari sensor regangan (strain gauge) yang melalui sirkuit jembatan $\mathrm{H}$ selanjutnya masuk alat signal conditioning dengan frekwensi responsif sekitar $500 \mathrm{kHz}$. Sinyal yang berasal dari sensor regangan diperkuat intensitasnya tegangannya dan luaran sinyal dari alat signal conditioning masuk ke alat Data Logger. Alat Data Logger yang digunakan adalah merek National Instruments dengan spesifikasi NI USB-609. 


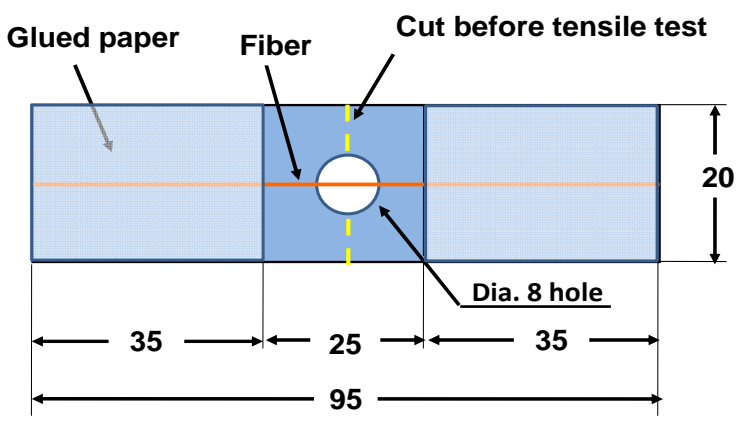

Gambar 5. Bentuk dan ukuran spesimen uji tarik JIS K-7601

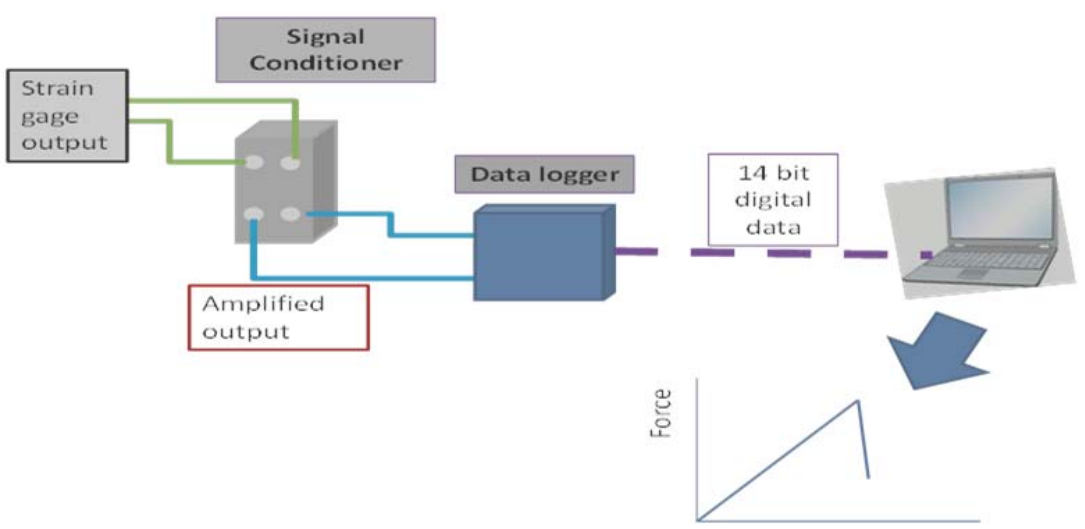

Gambar 6. Sistem akuisisi data.

Data Logger tersebut mempunyai resolusi sebesar 14 bit dan mempuyai kecepatan pengambilan data $48 \mathrm{k}$ sinyal/detik. Data dikonversikan ke dalam 14 bit data digital untuk disimpan sebagai fungsi waktu dalam komputer. Dengan demikian, kita akan dengan mudah dapat mengukur gaya kekuatan tarik dari spesimen uji tarik serat alam ketika data disimpan dalam komputer.

\section{HASIL DAN PEMBAHASAN \\ Prinsip Kerja Alat}

Batang cantilever ini dipasang tetap pada rangka kolom mesin dengan dijepit pada sepasang plat baja. Dua buah strain gauges dipasang pada batang cantilever dengan jarak $10 \mathrm{~mm}$ dari penjepit dan dipasang pada posisi atas dan bawah. Pada ujung bebas dari batang cantilever dipasang satu penjepit spesimen seperti pada Gambar 7 kabel penarik spesimen grip dari atas terbuat dari benang pancing, dengan panjang $400 \mathrm{~mm}$ dan kekuatan tarik 40 pound, digunakan untuk menarik spesimen serat alam. Satu ujung benang pancing dihubungkan ke pemegang grip dan satu ujung lagi terikat pada roda. Penarik beang pancing menggunakan motor listrik jenis gear box reduksi dengan kecepatan putar 1 rotation/minute. Pada saat motor listrik dihidupkan maka spesimen akan tertatik dan ujung batang cantilever akan mengalami penarikan secara bebas terhadap besarnya gaya tarik spesimen. Kemudian, hasil dari dua strain gages secara proportional akan mengalami tegangan sebesar gaya yang diberikan. Sebelum memulai melakukan uji tarik spesimen serat alam, output dari strain gauges terlebih dahulu harus dikalibrasi dengan meteran gaya. Menggunakan kurva kalibrasi, kita dapat mengukur besaran gaya yang diperlukan sampai spesimen uji tarik serat alam terputus seperti terlihat pada Gambar 7.

\section{Kalibrasi Alat}

Untuk mengukur besarnya pembebanan yang diberikan kepada spesimen uji tarik, tegangan output dari strain gauges yang dipasang pada batang cantilever maka harus dikonversikan kedalam besaran gaya yang diterima oleh spesimen. Kurva kalibrasi antara tegangan output dengan beban yang diberikan dapat digambarkan seperti pada Gambar 8. Pada tahap ini, kita ketahui bahwa 
besarnya beban yang diberikan pada ujung cantilever serta tegangan output dari strain gauges yang selanjutnya masuk ke signal conditioner akan terekam.

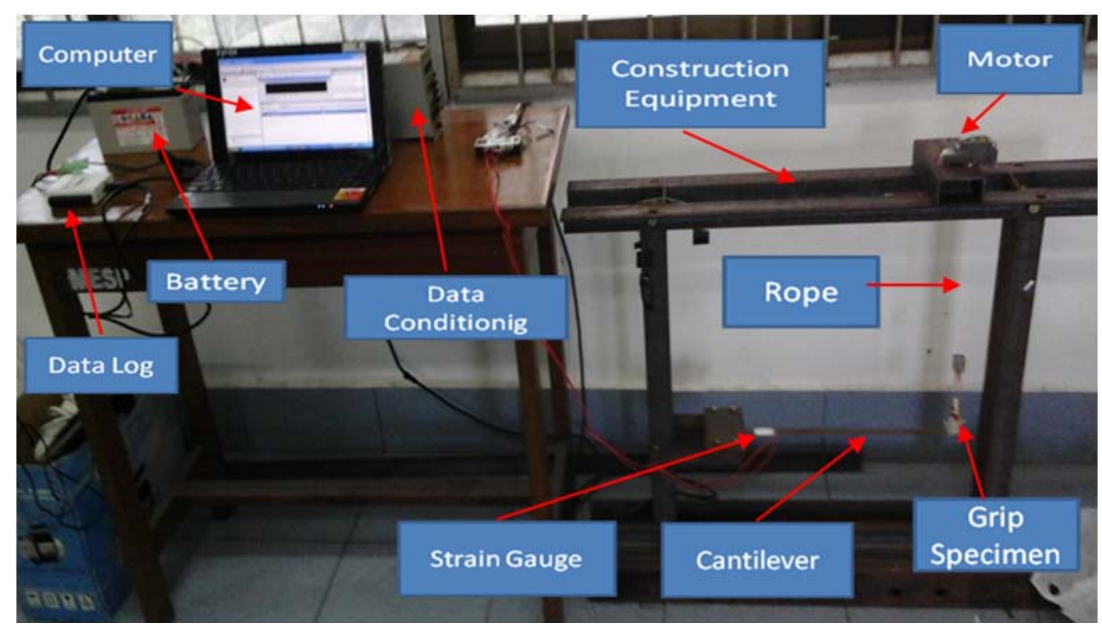

Gambar 7. Prototype alat uji tarik hasil rancangan.

Seperti terlihat pada Gambar 7, bahwa semua data pengukuran terletak pada kurva kalibrasi. Ini berarti bahwa alat uji tarik serat alam yang di rancang bangun oleh peneliti dapat digunakan dengan baik dalam mengukur kekuatan tarik serat alam. Garis lurus kurva kalibrasi dapat dilukiskan sebagai berikut:

$\mathrm{N}=1,052 \mathrm{~V}$

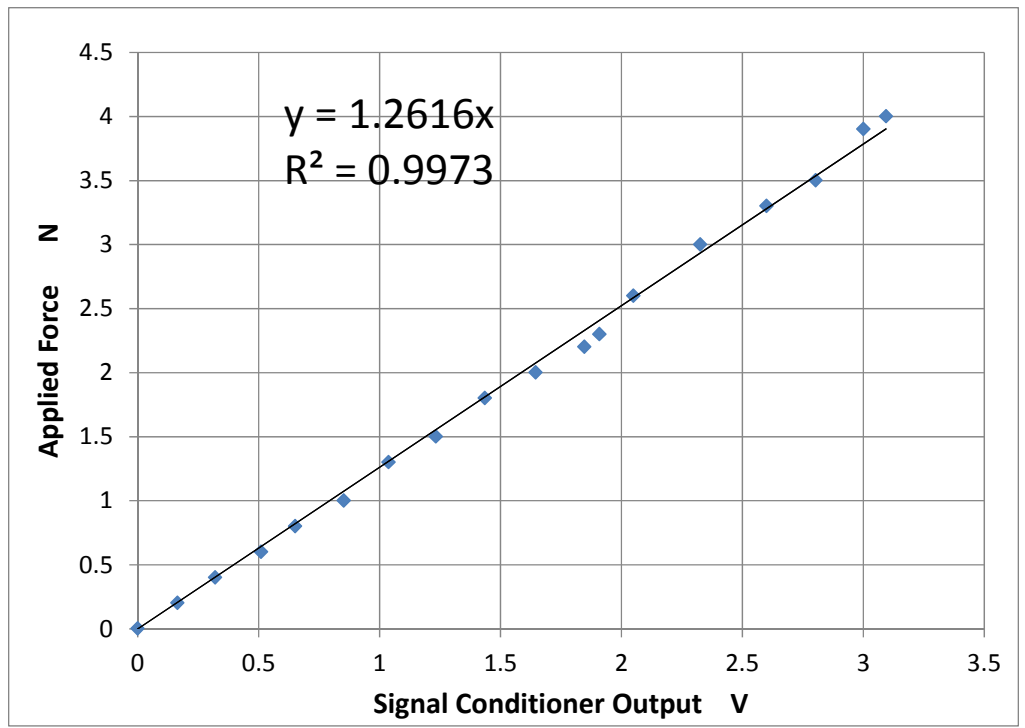

Gambar 8. Kurva kalibrasi terhadap gaya yang diberikan, N.

Dengan: $\mathrm{N}$ adalah besarnya beban yang diberikan pada spesimen, dan $\mathrm{V}$ adalah besarnya tegangan output yang keluar dari peralatan signal conditioner. Pada Gambar 8 terlihat bahwa koefisien determinasi sebesar 0,9973, ini menandakan bahwa hubungan antara variabel $\mathrm{N}$ dan $\mathrm{V}$ adalah berkorelasi garis lurus.

\section{Pengukuran Beban Putus}

Sistem akuisisi data berguna untuk konversi data analog ke data digital yang didapatkan selama proses uji tarik berlangsung dan data tersebut disimpan dalam komputer. Output data digital tersebut ditabulasikan kedalam lembaran excel sebagai fungsi dari waktu untuk menghitung beban 
putus dari serat abaca. Data yang tercatat di eksport kedalam data sheet seperti yang diperlihtakan pada Gambar 9. Pada koordinat sumbu horizontal dari kiri ke kanan, tegangan output dari signal conditioner diperlihatkan. Beban yang diaplikasikan terlihat bertambah besar secara linier terhadap bertambah waktu dengan besarnya laju pembebanan (loading rate) adalah 0,014 N/s.

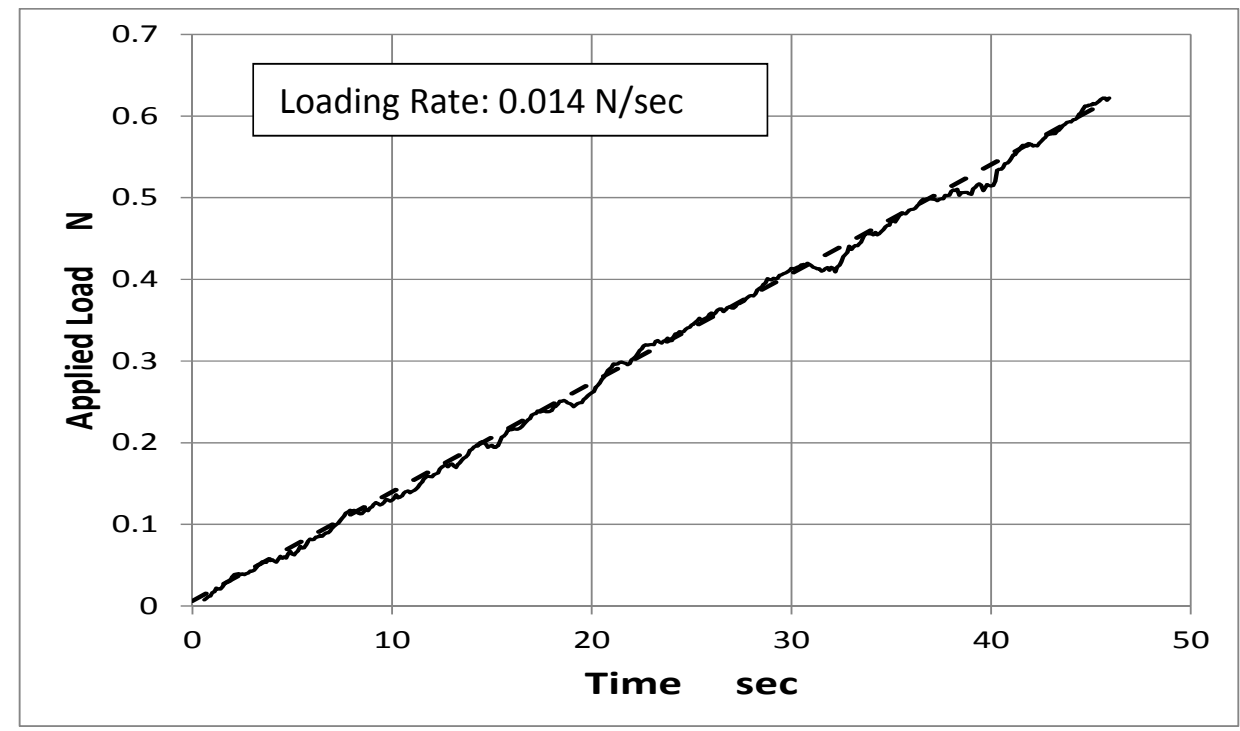

Gambar 9. Laju dari waktu vs pembebanan

\section{Hasil Pengukuran Uji Tarik}

Serat alam yang dijadikan spesimen uji tarik untuk pengujian alat ini adalah Serat Pisang Abaca (Abaca Musatexilis Nee) yang diambil dari Desa Alue Seunong, Kecamatan Indra Jaya, Kabupaten Aceh Timur.

Tabel 1. Diameter dan Kekuatan Tarik serat Abaca Aceh Timur.

\begin{tabular}{cccccc}
\hline $\begin{array}{c}\text { No. } \\
\text { SP }\end{array}$ & $\begin{array}{c}\text { Diameter } \\
(\mathbf{m m})\end{array}$ & $\begin{array}{c}\boldsymbol{\sigma} \\
(\mathbf{M P a})\end{array}$ & $\begin{array}{c}\text { No. } \\
\mathbf{S P}\end{array}$ & $\begin{array}{c}\text { Diameter } \\
(\mathbf{m m})\end{array}$ & $\begin{array}{c}\boldsymbol{\sigma} \\
(\mathbf{M P a})\end{array}$ \\
\hline 1 & 0.10 & 562.46 & 11 & 0.10 & 730.24 \\
2 & 0.07 & 888.06 & 12 & 0.12 & 801.94 \\
3 & 0.05 & 762.34 & 13 & 0.12 & 729.29 \\
4 & 0.13 & 538.77 & 14 & 0.13 & 503.59 \\
5 & 0.07 & 203.28 & 15 & 0.13 & 431.97 \\
6 & 0.05 & 812.43 & 16 & 0.14 & 623.26 \\
7 & 0.13 & 631.27 & 17 & 0.15 & 381.16 \\
8 & 0.09 & 313.43 & 18 & 0.19 & 279.55 \\
9 & 0.05 & 866.67 & 19 & 0.19 & 218.41 \\
10 & 0.08 & 740.03 & & & \\
\hline \multicolumn{7}{l}{ Rata-rata (average) } & & & $\mathbf{0 . 1 1}$ & $\mathbf{5 7 9 . 9 0}$ \\
\hline
\end{tabular}

Pada Tabel 1 dapat dijelaskan bahwa tegangan tarik serat abaca bergantung pada besarnya diameter serat. Untuk serat yang berdiameter kecil akan menghasilkan tegangan tarik yang besar. Diameter rata-rata serat abaca sebesar 0,11 mm dan tegangan tarik rata-rata sebesar 579,90 MPa. Hasil uji tarik yang didapatkan ini dikomparasikan dengan data hasil uji tarik yang ada pada literatur-literatur yang sudah ada maka terdapat kesesuaian dengan harga yang berkisar antara 200 MPa sd. $780 \mathrm{MPa}$ [13-14]. 


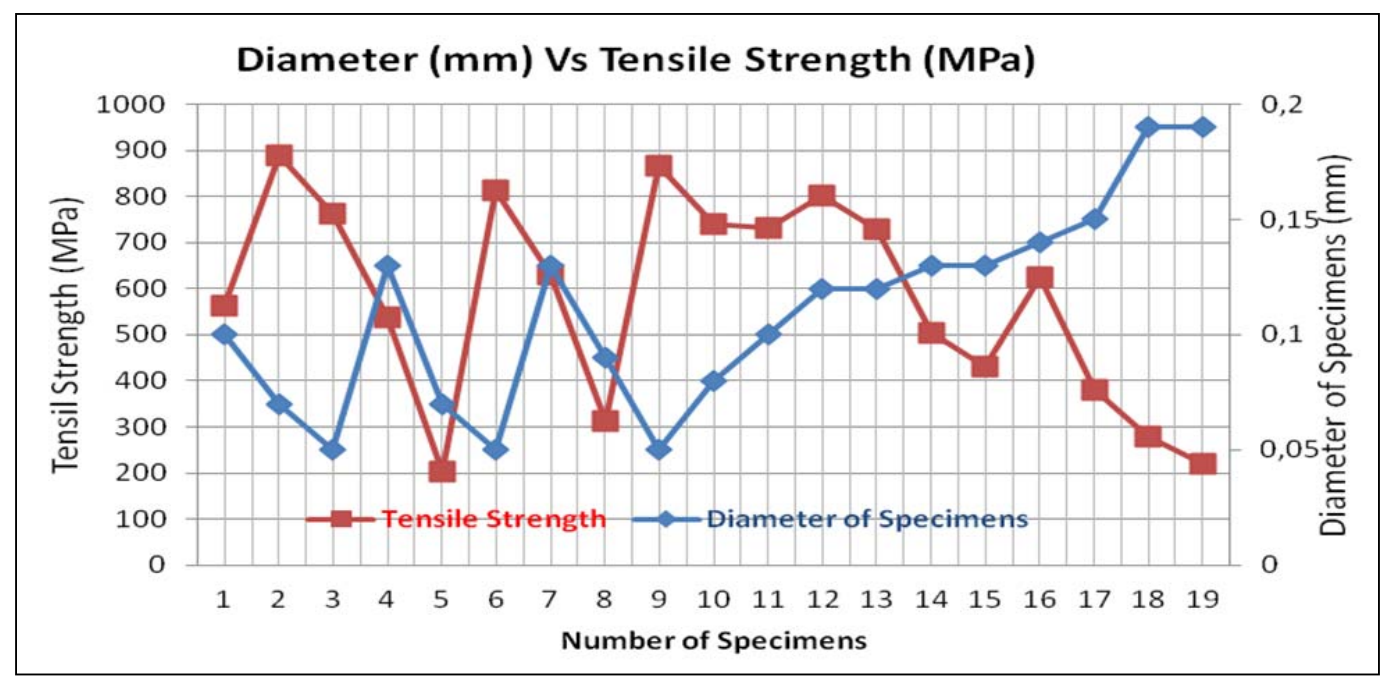

Gambar 10. Diameter vs kekuatan tarik Serat Abaca Aceh Timur.

\section{SIMPULAN}

Kesimpulan yang dapat diambil dari perancangan ini adalah: Telah berhasil dibuat prototype alat uji tarik serat alam serta uji coba. Data teknis adalah: Kapasitas pembebanan 5 N, ketelitian kurva kalibrasi: N=1,052 V dan laju pembebanan (loading rate) 0,014 N/s. Hasil uji tarik terhadap serat abaca diperoleh nilai kekuatan tarik rata-rata sebesar 579,90 MPa. Hasil uji tarik yang didapatkan ini dikomparasikan dengan data hasil uji tarik yang ada pada literatur-literatur yang sudah ada maka terdapat kesesuaan dengan harganya. Hasil penelitian ini diharapkan dapat memberikan manfaat bagi peneliti, akademisi dan industri dalam mendukung perkembangan industri serat alam nasional untuk peningkatan daya saing industri pada level internasional.

\section{DAFTAR PUSTAKA}

[1]. Brouwer, W. D. 2000. Natural fibre composites in structural components, alternative for sisal, On the Occasion of the Joint FAO/CFC Seminar, Rome, Italy.

[2]. Holbery, J. dan Houston, D. 2006. Natural-Fiber-Reinforced Polymer Composites in Automotive Applications, Low-Cost Composites in Vehicle Manufacture, JOM, November 2006.

[3]. Ramadevi P., et.al., (2014), Tensile Properties of Abaca Fiber Reinforced Polypropylene Composites, International Journal of Chemistry, ISSN: 2051-2732, Vol.35, Issue.2.

[4]. I. P. Kumar, (2010), Mechanical and Damage Characterization of Single Carbon and Glass Fibres, M. Tech. Thesis, Department of Aerospace Engineering, Indian Institute of Technology Kanpur, Kanpur Uttar Pradesh.

[5]. Prasanna Kumar Ilankeeran, Preetamkumar M. Mohite and Sudhir Kamle, (2012), Axial Tensile Testing of Single Fibres , International Journal Modern Mechanical Engineering, pp. 151-156.

[6]. ASTM D3379-75, (1975), Standard Test Method for Tensile Strength and Young's Modulus for High Modulus Single Filament Fibers,” ASTM Standards.

[7]. Y. Yamashita, S. Kawabata, S. Okada and A. Tanaka, "Mechanical Characteristics of PBO Single Fiber," 2003. www.mat.usp.ac.jp/polymer-composite/253.PDF

[8]. D. Sinclair, "A Bending Method for Measurement of the Tensile Strength and Young's Modulus of Glass Fibers,” Journal of Applied Physics, Vol. 21, No. 5, 1950, pp. 380-386. doi:+10.1063/1.1699670

[9]. “Torayca Carbon Fibres Technical Information,” http://www.torayca.com/ en/index.html

[10]. Djamasri, (2008), Prospek Pengembangan Komposit Serat Alam di Indonesia, Pidato Pengukuhan Jabatan Guru Besar pada Fakultas Teknik UGM, Yogyakarta. 
[11]. Y. Fukumoto, (1987), Guidelines for stability design of steel structure, Subcommittee on stability design committee on steel structures, Japan society of civil engineers, Tokyo Japan, October, pp.37-76.

[12]. Ke Liu, Hitoshi Takagi and Zhimao Yang, (2013), Dependence of tensile properties of abaca fiber fragments and its unidirectional composites on the fragment height in the fiber stem, International Journal Composite Part A.

[13]. Alfred Noufie Mekel, Rudy Soenoko, Wahyono Suprapto and Anindito Purnowidodo, (2016), Tensile Strenght of Abaca Strand freom Sangihe Talaud Island, ARPN Journal of Engineering and Applied Sciences, ISSN 1819-6608.

[14]. Suwardi, Hiroomi Homma and Abubakar, (2018), Identification of tensile strength properties of abaca fiber by weakest-linkage approach-statistic property of fiber diameter, IOP Conf. Series: Materials Science and Engineering 308 (2018) 012037 doi:10.1088/1757899X/308/1/012037. 